\title{
The Epistolary French Novel between History and Literature
}

\author{
Luisa Messina \\ University of Palermo \\ luisamess84@libero.it
}

\begin{abstract}
The eighteenth century is considered as the golden age of epistolary art. If we analyse the historical and social value of letters, we notice that epistolary exchange soon becomes one of the principal ways of communication and of providing information. One of the most important qualities of the epistolary novel is its ability to effectively convey emotion. The epistolary novel removes the temporal distance between personal history and its written form. The most famous writers of the time (such as Montesquieu) and libertine writers (Laclos and Sade in particular) employed the epistolary novel in different ways. So eighteenth-century literature is characterised by the successful epistolary novel. Since the Modern Age letter has held great historical and social importance due to the power of letter to act as a vehicle for information. This emerges as one of the main reasons for the rise in popularity of the epistolary novel.
\end{abstract}

Keyword: novel, letter, modern Age, Eighteenth-century, France.

\section{The EPistolary Novel in THE Eighteenth Century}

Thanks to progress in learning and in postal organization, the letter becomes an important medium for communicating information and can be viewed as a precursor to the modern gazette. So the evolution of the epistolary form facilitates news circulation concerning politics, literature, family and society: it's the main way used by aristocracy and bourgeoisie to find news (Grassi, $1994: 302$ ). So the readers are impatient to receive a letter to enliven an ordinary life. The value of a letter lies in several aspects considering that the "art" of letter writing under the Ancien Régime in France clearly has an ethic as well as an aesthetic importance, a politic as well as a poetic component. So letters published as "art" under Classicism are always transformed into illustrations of the "art" of writing letters where the writing subject is positioned as a loyal (male) servant of an aristocratic order revolving around an absolute $\mathrm{king}^{1}$. However, epistolary novel gives arise in the second half of the eighteenth century. The beginning of the Eighteenth is dominated by memoirs in which the protagonists offer their experience of life and love. The principle quality, attributed to a letter, is its capacity to transmit feelings immediately: in fact, a letter avoids temporal distance between lived experience and its written expression. In this way, the absence of a narrator guarantees the authenticity of narration because nobody can talk or think in place of characters (Burel, 2012: 506) ${ }^{2}$.

1. "This writer serves the monarch through public speech acts that constitute a predictable and universally imitable model of courtesy. The counter current to this dominant Classical model, which coexists with it from the outset, is epistolary 'art' interpreted as inimitable but inspiring emulation, because it is understood to emanate from differing, private literary spaces that articulate the particularities of historical contingency. The latter concept of epistolary art generates discourses of cultural difference, which will assume a renewed ascendancy in the eighteenth century" (Altman, 1986: 62).

2. P. V. Conroy analyses the principal elements concerning the French epistolary genre (epistolary choice, public and authenticity) in this way: "By adopting the epistolary format, the novel took upon itself that particular way of rendering the outside world that the letter had already conditioned the reading public to accept as normal. To the extent that fictitious novel followed the same conventions and satisfied the same expectations as did 


\section{Origins of The EPistolary Novel and The Principal French EPistolary Works}

The epistolary novel is a specific literary genre that is particularly loved by European authors during the Eighteenth century. The genre first appears in England and France and, later, in Germany. In fact, the epistolary novel is a millennium old if we consider that one of the first example is Heroines by Ovid who reproduces fictional correspondence between two lovers: except for three letters produced by men, all the women write to absent husbands and lovers, who apparently have other things to $\mathrm{do}^{3}$. During the Middle-Ages and the Modern Age several real epistolary exchanges (Saint Catherine from Siena, Erasmus, Cromwell and Madame de Sévigné) are published and read by a large audience ${ }^{4}$. But it's especially the rediscovery of Ovid's work during the Renaissance that sees an increase in the number of readers of those letters: so their authenticity is questioned. However, the first epistolary French novel is Astrée by Honoré d'Urfé published at the beginning of the seventeenth century (between 1607 and 1627). But the epistolary novel becomes very popular only in the second half of the seventeenth century after the publication of Lettres portugaises (1669) by Guilleragues $(1669)^{5}$. The novel is focused on Marianne's suffering: the girl, who is abandoned by a young and charming French officer, writes a series of letters in which she expresses her grief after her lover's escape. The technique is not innovative because it is inspired by Saint Augustine's Confessions. However, Marianne describes her interior struggle as being characterised by flux and reflux between reminiscences and dreams, judgements and

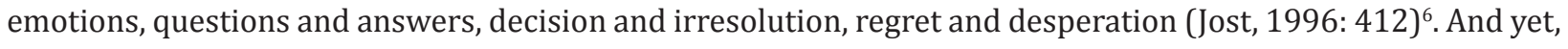
Lettres portugaises represents the first example of an epistolary novel with one voice centred on feelings and it inaugurates a long tradition according to the Portuguese model. Among different writers using the epistolary technique, Laclos is the only one able to personalise the epistolary novel transforming it into a war bulletin in which characters confess to each other their battle plans and strategic lies.

The Eighteenth century manifests the triumph and the end of the epistolary genre linked to the increasing presence of femals: women become writers and readers ${ }^{7}$. The history of letter books during and after real letters, they qualified as authentic and enjoyed the same 'real' status as the true letters they resembled in format and content" (Conroy, 1981: 413).

3. It is said Ovid's Heroides is an Ovid's exercise when Latin author is studying for a law degree because legal rhetorical training in Rome includes the art of writing of imaginary speeches and epistle. Actually, no other classical work gives women characters such different and precise voices (Beebee, 1999: 106).

4. The letter is considered as the most prominent and often-used literary form which is reserved to female voice and experience. In other words, epistolary novel is a sub-literary genre to which women are condemned by the hierarchy of genre: "The epistolary novel became an important cultural vehicle for living women a voice, both as characters and as authors. Arguably, Western literature had never produced an array of female characters at once realistic and eloquent as it did starting with Mariana (the Portuguese nun) and continuing through Richardson's Pamela and Clarissa, Graffigny's Peruvian princess, Rousseau's Julie, and Laclos's Madame de Merteuil (Beebee, 1999: 105).

5. Considering the publication of Lettres portugaises, it is easy to recognize a significant change. In the Renaissance women can abashedly publish their own letter books and broach the same range of topics as men. In seventeenth century women's letters are rarely turned into letter books: they write anonymously and against their wills. In fact, authorship in the seventeenth century becomes a male-dominated institution, deeply connected, moreover, to political hierarchies (Altman, 1986: 45).

6. Also in this case authenticity is questioned. However, Beebee argues Lettres portugaises can be considered as genuine because no man could disorder his prose so beautifully (Beebee, 1999: 117).

7. Successful epistolary novel corresponds to the spread of manual letters which give a model for different kinds of letters. So there are letters for those who have not taken leave of their parents before a trip, a letter from a father writing to his son who is in Paris, a letter to another son to make renounce to a duel and a letter from a mother to a daughter staying in a convent (Altman, 1992: 869).

Writing-letters manuals do not end in the eighteenth century. Between about 1830 and the turn of century 195 
the eighteenth century is marked by an awareness of the relational differences between oral conversation, handwriting, and print as modes of interpersonal communication, as representations of temporally specific experience, and as conveyors of social values ${ }^{8}$. At the beginning of the eighteenth century Lettres persanes (1721) by Montesquieu is published. Montesquieu shows a certain internal coherence because the letters come from the same character which maintains a kind of psychological unit. In fact, the main characters (Rica and Usbek) send a lot of letters to their other friends who, however, do not answer. In this case the epistolary technique, associated with exotic taste, is useful for hiding the writer's political, social and philosophical convictions: two travellers harshly criticise Parisian institutions and habits. Inspired by Lettres persanes and its disoriented voyager, Voltaire composes Lettres philosophiques ou anglaises (1734) where his choice to write in the epistolary form is only functional, used to develop topics loved by Enlightenment such as religion, politics, economics, philosophy, etc.. The goal is to propose England as a model of an enlighten monarchy which is opposed to French absolutism. Other writers make use of the epistolary novel to give voice to emotional torments which exhaust their protagonists. In fact, Madame de Graffigny creates Lettres d'une péruvienne (1747) adopting the model proposed by Lettres portugaises. The young Zilia writes to her lover, who has become unfaithful, and refuses the approaches of a French admirer. Zilia can be likened to an Usbek, a female Rica, because she arrives in France where she talks about French society in the Eighteenth century (Jost, 1996: 413). However, her letters show her great feeling (unrewarded love and quivering sensibility). Moreover the same sentimental climate is visible in La nouvelle Héloïse (1761), one of the most famous epistolary novel of the eighteenth century, in which Rousseau make recourse to fictional letters in order to recreate a private world, which is the expression of his personality 9 . According to Rousseau, the epistolary novel is the most proper form able to manifest his sensitive soul, his dreams and, finally, his need to love and to be loved: Rousseau is successful to unit Madame de Graffigny's morality and Crébillon's exotics (Fellow, 1972: 35). Madame de Staël, admiring Rousseau's novel, says that : "Rousseau n'a rien inventé, mais il a tout enflammé » (Rousseau has invented nothing, but he has exaggerated everything). Despite Rousseau's intentions, libertine writers can give voice to their desires dominating both sexes.

\section{EPISTOLARY NOVEL IN LIBERTINE LITERATURE}

Certain libertine writers (such as Crébillon, Meusnier de Querlon, Laclos and Sade) employ the epistolary genre neither to express characters' desires nor to show the effects produced by letters on characters. Then some libertine novels such as Letters de la marquise de $M^{* * *}$ au comte de $R^{* * *}$ and La Tourière des carmélites concern the point of view a protagonist who writes to a single receiver. For example, in Lettres de la marquise de $M^{* * *}$ au comte de $R^{* * *}$ Crébillon transfers struggle from the convent to the sitting room, focusing attention on one Madame's sentimental trouble. This noble woman writes to his lover whose reactions are reproduced though allusions made by the woman. So the main conflict involves a desperate woman struggling between respect for her moral system (but which is inadequate) and her sexual desires. Her destiny reflects aristocracy's decline: courteous love has now disappeared and been replaced by lustful passions having no value. In La Tourière des carmélites Meusnier de Querlon chooses the epistolary novel in order to express feeling of Agnès, best known as Sainte Nitouche, who composes her memoirs though several letters addressed to a nun.

titles are published in 616 different editions by 143 different publishers (Chartier, 1997: 3).

8. After French Revolution autograph letters are used in order to authenticate some original manuscripts: "Autograph letters become the object of a veritable cult, significantly intensified and commercialized after the Revolution by the dispersion of manuscript collections and by the technology of facsimile printing, which enabled collectors to identify authentic originals more readily (Altman, 1986: 60).

9. According to Altman, Rousseau and Richardson share same vision concerning letter: "in Pamela, Clarissa, and La Nouvelle Heloïse, Richardson and Rousseau will project a similar, albeit secularized, vision of the value of the letter book as the documentary record of an exemplary life, to be reread and imitated by a community inspired by the saintly model" (Altman, 1986: 47).

American Research Journal of English and Literature

Page 3 
On the other hand, some epistolary libertine novels such as Les Liaisons dangereuses and Aline et Valcour suggest a richness of voice offering to readers a privileged position because they are the only ones to read all of the letters written by different people. For example, the same event is related from different points of view and then interpreted by the character who is narrating. In Les Liaisons dangereuses the same event at the Opera, where Valmont is accompanied by courtesan Émilie, is recounted in three different letters. So we are unaware if Valmont is indeed sincere when he writes to marquise de Merteuil and to Madame de Tourvel. So the polyphonic epistolary novel reveals truth as a problematic question because it does not exist outside different points of view (Burel, 2012: 509). This polyphonic novel shows letter that the can link the marquise de Merteuil with four people like Valmont and Madame of Volanges; Madame de Tourvel maintains relationships with three confidantes like Cécile; Danceny communicates with five addressees. We can also observe a precise distribution of letters among different couples: in particular, the most significant epistolary exchanges are between Valmont and marquise of Merteuil; Valmont and Madame de Tourvel; Cécile and chevalier de Danceny. However, they are two libertine characters (Valmont and marquise) that determine and, at the same time, dominate other epistolary exchanges. Besides, libertine characters need a public because their success is intimately associated with their social reputation. Both of them sometimes feign tragedy because they are not able to express the most sincere feelings. One of the most important letters is certainly letter eighty-one in which the marquise de Merteuil gives expression to her real feelings explaining when and how she is become a hypocrite cynic ${ }^{10}$.

Finally, in Les Liaisons dangereuses the letter is not simply a means of conveying information, but it becomes either a weapon of seduction, used by Valmont in order to spite Madame de Tourvel, or a battle weapon between Valmont and the marquise de Merteuil. In fact, letters written by Valmont and the marquise de Merteuil symbolise a social representation, which they required in order to maintain their leadership ${ }^{11}$. If we analyse Les Liaisons dangereuses's function in the libertine novel as a whole, critics point out that Laclos's novel represents, on the one hand, epistolary novel's triumph and, on the other hand, its death. Certain researchers notice that, even if Laclos's novel remains the epistolary novel's masterpiece, Les Liaisons dangereuses shows the influence of other epistolary novels in the eighteenth century (such as Clarissa and La nouvelle Héloïse). It is not surprising to see the widespread diffusion of Richardson's novel and Rousseau's novel, if we consider the number of new editions that have been published ${ }^{12}$. For instance, Clarisse (1751) amounts to ten new editions whereas La nouvelle Héloïse (1761) has more than thirty-five new editions (Martin, 1970: 387-88). B. Didier analysed Laclos's sources: Crébillon's Les égarements du cœur et de l'esprit where Versac can be considered as Valmont's precursor; Rousseau's La nouvelle Héloïse et Molière's Tartuffe de Molière (Didier 13). It is, however, worth pointing out a relevant difference between Rousseau and Laclos. Firstly, Rousseau's letters express common language characterising the most beautiful souls, which is the same as that revealed by Rousseau in other works. Despite Rousseau, Laclos shows how way of writing can manifest a different style (Burel 516). For example, in Les Liaisons dangereuses young Cécile writes in a very clear and innocent way while the marquise

10. “Entrée dans le monde dans le temps où, fille encore, j'étais vouée par état au silence et à l'inaction, j'ai su en profiter pour observer et réfléchir [...] Ressentais-je quelque chagrin, je m'étudiais à prendre l'air de la sérénité, même celui de la joie ; j'ai porté le zèle jusqu'à me causer des douleurs volontaires, pour chercher pendant ce temps l'expression du plaisir [...]. J'étudiai nos mœurs dans les romans ; nos opinion dans les philosophes ; je cherchai même dans les moralistes les plus sévères ce qu'ils exigeaient de nous, et je m'assurai ainsi de ce qu'on pouvait faire, de ce qu'on devait penser, et de ce qu'il fallait paraître" (Laclos, 2012: 214-217).

11. If Laclos proposes a female liberation, Rétif demonstrates a conservative point of view. In La femme infidèle he points out female sexual liberation causes emasculation and death of the male. So the anti-heroine of $L a$ femme infidèle is compared to Sappho, an Ovid's character (Beebee, 1999: 123).

12. Richardon's letters show a connection between genuineness and fictionality representing reading attitude in the second half of the eighteenth century. On the one hand, publication implies doubt rather than feeling of facticity because handwriting cannot be used to testify authenticity. On the other hand, readers seem to apply "Historical Faith" to any sort of published letters (Beebee, 2007: 65). 
de Merteuil displays a more sophisticated style expressing her false proposals. Another example concerns the chevalier de Danceny whose style is a pastiche coming from lyric language used by Saint-Prieux in Rousseau's La nouvelle Héloïse. This pastiche is remarkable through either the use of apostrophes and lyric questions or a vocabulary full of sensibility. So it is normal for Valmont and the marquise de Merteuil to criticise Danceny's writing style compared to a traditional novel's beautiful hero (Burel, 2012 : 519). Secondly, La nouvelle Héloïse is a novel concerning positive sentimental education in order to create a sensitive individual and ideal society, while in Les Liaisons dangereuses the couple formed by Cécile and chevalier de Danceny receives a negative sentimental education determining, on the one hand, the end of ideal love and the separation, on the other hand. The dispersion of two lovers (Cécile goes to a convent and Danceny renounces life amongst the rest of society) is opposed to Clarens's happy community described by Rousseau. However, Laclos's theory is inspired by Rousseau's conception: in fact Rousseau affirms that the novel is dangerous to young ladies who are not supervised by their mothers. So Laclos thinks girls should read travel writing and translations, learn foreign languages (such as Italian and English) and scientific disciplines such as physics, chemistry, natural history and botany (Didier, 1998: 27).

If we analyse the importance attributed to the letter, we can affirm that Laclos'novel is inspired by Clarissa, considered as an epistolary masterpiece by the same Laclos. In fact, Richardson makes use of the letter as instrument for seduction. If Madame de Tourvel (Les Liaisons dangereuses) is completely aware when she gives Valmont's plan away, Clarissa is stunned by Lovelace who seduces her before dying in a duel.

In conclusion, Laclos revolutionised how Rousseau used the letter. Rousseau maintains that epistolary exchange can constitute the ideal expression of a transparent communication, unlike Laclos who recounts symptoms of general perversion concerning aristocratic society, characterised by corruption (Ansart, 2003: 273). So contemporary research considers literary libertinage as anticipation precursor to the French Revolution because it shows a doomed society (Cazenobe, 1991: 11).

\section{The Epistolary Novel During The French Revolution}

The French novel during the Revolution does ever links with the traditional novel characterising the Eighteenth century because techniques are essentially the same that is to say the third person narrator and the epistolary novel in the first person. After Les Liaisons dangereuses, writers are not able to achieve the same artistic and formal perfection as Laclos. So the epistolary novel declines quickly and before 1799 this genre has almost disappeared. However, we find two examples regarding representative epistolary forms inspired by the libertine tradition such as Sade's Aline et Valcour (1796) et and Sénac de Meilhan's L'émigré (1797). The first one collects a series of letters written by two protagonists and certain secondary characters focussing the attention on Aline and Valcour's uncertain destiny: their love is forbidden by president de Biamont who wants give her daughter to his old friend Dolbourg. Letters are divided between the development of a tragic love and the description of exotic settings. However, all critics affirm that Sade cannot achieve Laclos's perfection because Sade's style is more similar to that of Richardson (Fellows, 1972: 36). The second novel (L'émigré) is quite different because its author chooses the epistolary genre in order to focus on fragmentary form and subjective form which serve to narrate certain revolutionary events. Through the characters' point of view, readers are witness to some episodes pertinent to contemporary France, such as the beginning of the French Revolution in July 1789, royal weakness, the minister Necker, October's events causing the royal transfer from Versailles to Paris, the execution of the king symbolising the end of the monarchy ${ }^{13}$.

13. At the beginning of the novel, Sénac de Meilhan explains his purpose: "Tout est vraisemblable, et tout est romanesque dans la révolution de la France ; les hommes précipités du faîte de la grandeur et de la richesse, dispersés sur le globe entier, présentent l'image de gens naufragés qui se sauvent à la nage dans des îles désertes, là chacun oubliant son ancien état est forcé de revenir à l'état de nature ; il cherche en soi-même des ressources, et développe une industrie et une activité qui lui étaient souvent inconnues à lui-même. Les rencontres les plus 


\section{CONCLUSION}

It is worth concluding that the epistolary novel, although it was not born in the eighteenth century, has great importance during the century of Enlightenment and it disappeared only gradually. Even if the origins of epistolary art come from classical literature (Ovid) and French modern literature (such as the novels L'Astrée and Portuguese Letters), the epistolary novel becomes one of the most successful genres in modern literature. So different novelists choose the epistolary technique to achieve some intentions. At the beginning of the eighteenth century the most famous French writers such as Montesquieu and Voltaire make use of epistolary novel to discuss several faults concerning absolutist France. Later novelists (such as Madame of Graffigny and Rousseau) use the epistolary technique to stress their characters' magnificence. Starting with the French masterpiece of the genre La nouvelle Héloïse (1761) by Rousseau, the middle of the eighteenth century offers a series of libertine epistolary novels like Lettres de la marquise de $M^{* * *}$ au comte de $R^{* * *}$ and La Tourière des carmélites: for instance, Meusnier of Querlon shows libertine career of a young girl who reveals herself though letters. Other libertine writers (such as Laclos and Crébillon) adopt the epistolary form as a sharp instrument to criticise certain social aspects such as aristocratic corruption: in 1782 Laclos writes Les liaisons dangereuses, celebrated as the last example of the genre. Other epistolary novels like L'émigré and Aline et Valcour appear during the revolutionary period with different purposes: in the case of Sénac de Meilhan the epistolary novel is used to denounce revolutionary excess. So the variety seen in the French epistolary novel shows the richness of the genre which is particularly loved by readers during the Enlightenment. In fact readers have loved this kind of narration for its charm of authenticity and for the fact that it allows them follow a story which has the appearance of a real life story.

\section{REFERENCES}

Altman Janet Gurkin, "The Letter Book as a Literary Institution 1539-1789: Toward a Cultural History of Published Correspondences in France", in Yale Studies, Special Issue "Men/Women of Letters", Volume 71, 1986, pp. 17-62.

Altman Janet Gurkin, "Epistolary Conduct: The Evolution of the Letter Manual in France in the Eighteenth Century", in Studies on Voltaire, Volume 304, 1992, pp. 866-870.

Ansart Guillaume, "Love, pleasure and subjectivity in $18 \mathrm{t}^{\mathrm{h}}$ century French novel", in Eighteenth-century Studies, Vol. 36, No. 2, 2003, pp. 270-275.

Beebee Thomas O., Epistolary Fiction in Europe, 1500-1850, Cambridge, Cambridge University Press, 1999.

Beebee Thomas O., "Publicity, Privacy, and the Power of Fiction in the Gunning Letters", in Eighteenth Century Fiction, Volume 20, No. 1, 2007, pp. 61-88.

Burel Charlotte, "Le texte en perspective", in Pierre-Ambroise-François Choderlos de Laclos, Les liaisons dangereuses. Paris : Gallimard, 2012, pp. 489-545.

Cazenobe Colette, Le système du libertinage de Crébillon à Laclos, Oxford, Voltaire Foundation, 1991.

Chartier Roger, "Introduction: An Ordinary Kind of Writing: Model Letter and Letter-Writing in Ancien Regime France", in Correspondence. Models of Letter-Writing from the Middle Ages to the Nineteenth Century, Cambridge, UK Polity, 1997, pp. 1-23.

Conroy Peter V., "Real Fictions: Authenticity in the French Epistolary Novel”, in Romanic Review, Vol. 72, No. 4, 1981, pp. 409-424.

extraordinaires, les plus étonnantes circonstances, les plus déplorables situations deviennent des événements communs, et surpassent ce que les auteurs de roman peuvent imaginer" (Sénac de Meilhan, 2004: 33). 
The Epistolary French Novel between History and Literature

Didier Béatrice, Choderlos de Laclos: Les Liaisons dangereuses. Pastiches et ironies. Paris, Éditions du temps, 1998.

Fellows Otis, "Le roman épistolaire français", Dix-huitième siècle. No. 4, 1972, pp. 17-38.

Grassi Marie Claire, "L'art épistolaire français, XVIII et XIXe siècle" in Pour une histoire des traités de savoir-vivre en Europe, Clermont-Ferrand, Publications de la Faculté des Lettres et Science Humaines de ClermontFerrand, 1994, pp. 301-366.

Gurkin Hatman Janet, "The Letter Book as a Literary Institution 1539-1789: Toward a Cultural History of Published Correspondences in France Author(s)", in Yale French Studies, No. 71, 1986, pp. 17-62.

Hartmann Pierre, Le contrat et la séduction. Essai sur la subjectivité amoureuse dans le roman des Lumières, Paris, Champion, 1998.

Jost François, "Le Roman épistolaire et la technique narrative au XVIII e siècle", in Comparative Literature Studies, Vol. III, No. 4, 1996, pp. 397-427.

Laclos Choderlos de Pierre-Ambroise-François, Les liaisons dangereuses, Paris, Gallimard, 2012.

Martin Angus, "Romans et romanciers à succès de 1751 à la Révolution d'après les rééditions", in Revue des Sciences Humaines, No. 35, 1970, pp. 383-389.

Nagy Peter, Libertinage et révolution, Paris : Gallimard, 1975.

Rousset Jean, “Les lecteurs indiscrets", in Laclos et le libertinage, Paris, P.U.F., 1983, pp. 89-96.

Sénac de Meilhan Gabriel, L'émigré [1797], Paris, Gallimard, 2004.

Citation: Luisa Messina, "The Epistolary French Novel between History and Literature" American Research Journal of English and Literature, vol 3, no. 1, 2017, pp. 1-7.

Copyright (C) 2017 Luisa Messina, This is an open access article distributed under the Creative Commons Attribution License, which permits unrestricted use, distribution, and reproduction in any medium, provided the original work is properly cited. 